\title{
A tőzsdei elszámolóházak vesztesége
}

A válságot követő új szabályozás a tőzsdén kívüli piacokon is egyre inkább megköveteli a kereskedés központi elszámolását, ezért rendszerkockázati szempontból kiemelt kérdés a tőzsdei elszámolóházak kockázatkezelése és azon belül a veszteségek vizsgálata. Ebben a cikkben az elszámolóházak általános müködését modellezzük, majd az amerikai határidős részvénypiac elmúlt nyolcévi adatai alapján szimuláljuk az alapletét elégtelenségéből adódó veszteségeket. Végül megvizsgáljuk az elszámolóház veszteségei és egyes külső stressztényezők, például egy amerikai általános stresszindex (CFSI) komponensei közötti kapcsolatot. Fő megállapításunk, hogy egy általános stresszindex kevésbé alkalmas az elszámolóház veszteségeinek előrejelzésére, mint egy saját fejlesztésü, testre szabott modell, aminek fö oka az lehet, hogy az elszámolóházak számos speciális tulajdonsággal - magas fokú specializáció, szimmetrikus kitettségek, letéti számlák útvonalfüggősége stb. - rendelkeznek. Journal of Economic Literature (JEL) kód: G15; G23; G28.

\section{Bevezetés}

A pénzügyi termékek kereskedése és elszámolása hagyományosan eltérő annak függvényében, hogy tőzsdei vagy tőzsdén kívüli (over-the-counter, OTC) piacról beszélünk. A tőzsdéken minden megbízás egy központi partneren, az elszámolóházon (klíringházon) keresztül teljesül, amelynek fö feladata, hogy minden ügylet ellenkező oldalára kereskedési partnerként beálljon. A tőzsdei központi elszámolóházak tehát átveszik a partnerkockázatot, így a kereskedési partnerek csak a központi elszámolóház hitelkockázatának vannak kitéve. Partnerkockázatuk csökkentése érdekében az elszámolóházak komplex letéti és napi elszámolási rendszert müködtetnek, amelyet

\footnotetext{
Berlinger Edina tanszékvezető egyetemi docens, Budapesti Corvinus Egyetem. Kutatását az MTA Bolyai János Kutatási Ösztöndíj Programja támogatta.

Dömötör Barbara egyetemi adjunktus, Budapesti Corvinus Egyetem (e-mail: barbara.domotor@ uni-corvinus.hu).

Illés Ferenc doktoranduszhallgató, Budapesti Corvinus Egyetem.

Váradi Kata egyetemi docens, Budapesti Corvinus Egyetem.

A kézirat első változata 2016. február 18-án érkezett szerkesztőségünkbe.

DOI: http://dx.doi.org/10.18414/KSZ.2016.9.993
} 
egy többszintű garanciarendszer is kiegészít, biztosítva, hogy a partnerek csődje esetén is minden ügylet biztonsággal teljesüljön.

A tőzsdén kívüli piac szereplői általában bilaterálisan számolnak el, ami jelentős partnerkockázatot jelent a szerződő felek számára. ${ }^{1}$ Bár ezen a piacon is lenne lehetőség a partnerkockázat kiszervezésére, azaz központi elszámolásra, a gyakorlatban a felek sokszor nem érdekeltek a kockázat továbbadásában. Ennek oka, hogy a klíringtevékenység „házon belül tartása" jelentös bevételt jelent a pénzügyi intézmények számára a felszámított tranzakciós költségek formájában közvetlenül, valamint a transzparencia hiányából adódóan közvetett módon. Nem meglepö, hogy a 2007-es válságot megelözően az OTC-ügyeleteknek csupán körülbelül 25 százalékát számolták el központi partneren keresztül (Hull [2015]). Az is megmutatható, hogy ha helyi szinten sikerül igazságos adósságrendezést kikényszeríteni, akkor a decentralizált klíring lényegében azonos eredményre vezet, mint a központi elszámolás (Csóka-Herings [2016]).

A válságra adott szabályozói válasz célja a pénzügyi rendszer stabilitásának és transzparenciájának növelése. Az új szabályozás - az Egyesült Államok kongresszusa által elfogadott Dodd-Frank Act, illetve az Európai Unió piaci szabályozása, a European Market Infrastructure Regulation (EMIR) - kikötötte, ${ }^{2}$ hogy minden jelentős piaci szereplő közötti, standardizált, tőzsdén kívüli ügyletet egy szabályozott központi szerződő félen (central counterparty, CCP) keresztül kell elszámolni. A központi szerződő felek hasonlóan működnek, mint a tőzsdén az elszámolóházak, sőt az esetek többségében ugyanazok az intézmények végzik mindkét tevékenységet. Ebben a cikkben a tőzsdei elszámolóházakat, illetve a tőzsdén kívüli piacok központi szerződő feleit azonos intézményeknek tekintjük, hiszen a különbségek (az utóbbiak esetében helyenként nincs napi elszámolás) egyre inkább eltünőben vannak.

Bár a központi elszámolás makroökonómiai következményeinek megítélésében nem egységes a szakirodalom, ${ }^{3}$ abban minden szerző egyetért, hogy a klíringtevékenység kiszervezésének hatékonysága a központi szerzödö felek mikroszintü stabilitásától függ. Ahhoz, hogy a változás ne csupán a „túl nagy a csődhöz” (too-big-to-fail) méretü bankoknak a „túl nagy a csődhöz” méretü központi szerződő felekre cserélését jelentse, kiemelt jelentőségü, hogy a központi szerződő felek megfelelő kockázatkezelési eljárásokat alkalmazva hatékonyan végezzék a tevékenységüket (Kiffés szerzötársai [2010], Hull [2015]). Hull [2015] azt hangsúlyozza, hogy ennek érdekében a központi szerződő feleket távol kell tartani a komplex pénzügyi tevékenységektől, azaz a elszámolóházak egyedüli céljául csak a partnerkockázat professzionális kezelését szabad kitüzni.

Az EMIR-szabályozás részleteiben meghatározza a központi szerződő felek kockázatkezelésének elemeit; néhány esetben azonban szabad kezet ad az intézményeknek az elöírások értelmezéséhez, illetve alkalmazásához. A stresszesemény is egy ilyen kevéssé definiált fogalom, annak ellenére, hogy több helyen is megjelenik explicit vagy implicit formában a szabályozásban, és központi szerepet tölt be a kockázatkezelés folyamatában:

\footnotetext{
${ }^{1}$ A vállalatok között is léteznek „klíringházak”, ezek a vállalati cash poolok, amelyek szintén hatnak a partnerkockázatokra (Walter-Kenesei [2015]).

${ }^{2}$ Dodd-Frank Act [2010], Európai Parlament és Tanács [2012], EB [2013].

${ }^{3}$ Lásd Pirrong [2009], Kiff és szerzőtársai [2009], [2010], Cont-Kokholm [2014].
} 
- stresszesemény, vagyis a biztosítéki igények nagymértékü, hirtelen megváltozása esetén, az elszámolóháznak nagyobb autonómiája van, hogy rugalmasabban tudjon reagálni a válságra (például az anticiklikus puffertől el lehet tekinteni);

- a kockázatkezelési modelleknek be kell épiteniük legalább egy tényleges stresszperiódust a stressztesztekbe, a forgatókönyv-elemzésbe és a modellkalkulációkba.

A cikkben egy ágensalapú modellt építünk, amely a pénzügyi eszközök központi elszámolását végző intézmény működését szimulálja, és ezen keresztül elemezzük az elszámolóház veszteségeit az amerikai tőzsdei határidős részvénypiac elmúlt nyolc éve alapján. Ezeket a veszteségeket összehasonlítjuk más pénzügyi stresszváltozókkal, és egy megfelelő stresszjelző modell kialakítására teszünk javaslatot. Megmutatjuk, hogy sokkal célravezetőbb egy testre szabott, az adott elszámolóház igényeihez kalibrált modell kifejlesztése, mintsem egy általános, piaci stresszindex alkalmazása, mivel az utóbbi nem veszi figyelembe a központi elszámolási iparág specialitásait.

A cikk felépítése a következő. Először egy hipotetikus klíringház tevékenységét ágensalapú szimulációval modellezzük, valamint megvizsgáljuk a vizsgált időszakban keletkezett veszteségek nagyságát és időbeli megjelenését. Ezt követően a piaci stresszmutatók alakulását elemezzük a vizsgált időszakban, és megvizsgáljuk a különböző modellbeállítások mellett generált veszteségek kapcsolatát a kiválasztott piaci stresszindexszel. Majd egy saját modellt kalibrálunk, ami jelentősen jobban teljesít a stresszesemények azonosításában. Végül, az utolsó pontban összefoglaljuk eredményeinket.

\section{Az elszámolóházak működésének modellezése}

A következőkben egy elszámolóház általános müködési modelljét mutatjuk be, majd szimuláljuk a hipotetikus tevékenységét, és ennek segítségével elemezzük a klíringtevékenység kockázatát. Az elszámolóház pozíciója modellünkben a kereskedés szimulációjából adódik, tehát a klíringpartnerek piaci paraméterek által befolyásolt tevékenysége okozza az elszámolóház kitettségét, ezáltal kockázatát. Az irodalomban vizsgált modellekben a klíringpozíciók egyéni vagy aggregált szintü, exogén inputadatként jelennek meg (Duffie és szerzötársai [2015]), vagy egy piaci adatokhoz kalibrált iterációs eljárás eredményeiként (Heller-Vause [2012]). Így tudtunkkal a miénkhez hasonló modell, amelyben a pozíciók időbeli alakulása nyomon követhető és a pozíciók a modell endogén változói, még nincs a szakirodalomban.

Az elszámolóházak kockázatkezelése sok szempontból hasonlít a bankok vagy más pénzügyi intézmények kockázatkezeléséhez, például az ügyfelek kockázati besorolása, veszteségeloszlások modellezése, kockázati mértékek számítása, letéti követelmények, garanciarendszerek meghatározása tekintetében. Számos szempontból azonban a központi szerződő fél tevékenysége eltér a pénzügyi intézményekétől, ami egyedivé teszi a kockázatkezelést is. Ezek a jellemzők a következö.

- Magas fokú specializáció. Az elszámolóházak rendkívül specializált intézmények, egyetlen jól definiált tevékenységük a partnerkockázat átvállalása és kezelése néhány meghatározott piaci szegmensben. Ez az „egy feladat-egy intézmény” 
típusú müködés kevésbé van kitéve az érdekkonfliktusoknak, ami növeli a transzparenciát és az elszámoltathatóságot.

- Szimmetrikus kitettségek. Az elszámolóházak lényegében egyenlö súllyal rendelkeznek vételi (long) és eladási (short) pozíciókkal; ennek következtében esetükben a stresszhelyzet egy szimmetrikusabb fogalom, mivel nemcsak egy áresés, de egy hirtelen felfelé történő árelmozdulás is jelentős partnerkockázatot hordoz.

- Kiegyensúlyozott pozíció. Az elszámolóházak semleges pozícióval rendelkeznek, vagyis a kockázati tényezőknek való nettó kitettségük nulla körüli. Így szemben a bankokkal és a befektetési társaságokkal, amelyek általában vételi pozícióban vannak az értékpapírpiacokon, az elszámolóházak közvetlenül nem érdekeltek a hosszú távú eszközhozamokban.

- Keresztgarancia-rendszer. Az elszámolóházak explicit keresztgarancia-rendszert üzemeltetnek, amely az összes ügyfelüket érinti. Ezért különösen lényeges számukra a különbözö piacok és ügyfelek közötti keresztkorreláció.

- Letéti számlák útvonalfüggősége. Az elszámolóházak korszerüen kidolgozott letétiszámla-rendszere napi elszámoláson alapul. Amennyiben az ügyfelek nem viszik el a felhalmozott nyereségüket egy kedvező irányú piaci elmozdulás után, akkor a biztosíték jóval magasabb lehet, mint amennyit a letéti előírások megkövetelnek. Ennek következtében a központi szerződő felek müködése biztonságosabbá, de egyben útvonalfüggővé válik.

- Dinamikus kockázatkezelés. Az elszámolóházak képesek dinamikusan fedezni a partnerkockázatukat azáltal, hogy napi szinten változtathatják a letéti követelményeket, ezért stresszhelyzetben aktív szerepük van.

Az alapletét meghatározása az elszámolóházaknál is - hasonlóan a banki szabályozói tőke meghatározásához - a legelterjedtebb kockázati mértékek, a kockáztatott érték (Value-at-Risk, VaR), valamint a várható alsóági veszteség (Expected Shortfall, ES) alapján történik, amelyeket más, széles körben elterjedt elemzési módszerekkel - a stresszteszt és a forgatókönyv-elemzés - egészítenek ki.

Az elszámolóház partnereinek veszteségét egy többlépcsős letéti és garanciarendszer (waterfall system) fogja fel, amelynek a végén az elszámolóház saját tőkéje áll. A garanciarendszer első lépcsőjét a klíringtagok saját letéti számlája jelenti, itt jelenik meg napi elszámolásban a veszteség. A veszteség fedezetére szolgál a tag által befizetett, szekciónként megállapított fix összegü kezdeti hozzájárulás, majd a későbbiekben a napi nyitott pozíciókon realizált piaci veszteségre, illetve a jövőbeli árváltozás fedezetéül előírt alapletét. Ha ez a fedezet nem bizonyul elegendőnek, a veszteség finanszírozására egy kollektív garanciaalap használható fel, majd az elszámolóház saját forrásai következnek.

\section{A modell}

Modellünkben számos egyszerüsítéssel élünk, a melyek közül a legfontosabb az, hogy kizárólag az első lépcsőt, vagyis az alapletét megfelelését vizsgáljuk, és azt értelmezzük veszteségként, ha a tag nem tesz eleget a letétfeltöltési kötelezettségének, így a 
pozíció likvidálásra kerül, és a rendelkezésre álló alapletét nem elegendő a veszteségek fedezetére.

A kereskedett részvények száma $M, S_{t}^{m}$ jelöli az $m$-edik részvény záró azonnali (spot) árfolyamát a $t$-edik napon. A részvényekkel a határidős piacokon kereskednek két lejáratra, mégpedig a két legközelebbi decemberre. A lejáratokat $T_{k}$ jelöli, ahol $k=1$ vagy 2 .

Az egyszerűség kedvéért az elszámolóház csak a határidős részvénypiacon aktív. ${ }^{4}$ A $t$-edik napi határidős árakat $\left(F_{t}^{m, k}\right)$ az arbitrázsmentes árazás elvén határozzuk meg: $F_{t}^{m, k}=S_{t}^{m} \cdot(1+r)^{T_{k}-t}$,

ahol $r$ a konstans kockázatmentes hozam, amelyet az egyszerüség kedvéért nullának tekintünk.

A potenciális kereskedőknek, vagyis az elszámolóház lehetséges partnereinek számát $N$-nel jelöljük. A kereskedők nem rendelkeznek többletinformációval; azaz véletlenszerűen kereskednek az egyes részvényekkel. Ebből az következik, hogy a kereskedés független az ártól. Másrészt feltesszük, hogy árak is függetlenek a kereskedéstől, például azért, mert a elszámolóházon keresztül lebonyolított ügyletek volumene elenyésző a teljes globális piachoz képest. Mindegyik kereskedő árelfogadó, és az adott napi záró árfolyamon kereskedik.

$\mathrm{Az} m$-edik részvény piacán a napon belüli kereskedések száma $\left(D_{t}^{m}\right)$ egy binomiális eloszlású sztochasztikus változó. Az ügyletek nagysága $\left(A_{t}^{m}\right)$ (vagyis a részvények darabszáma egy ügyleten belül) is binomiális eloszlást követ.

Egy ügylet az $i$-edik (long oldali) és a j-edik (short oldali) kereskedő között jön létre, ahol $i, j=1, \ldots, N$ és $i \neq j$. Az $i, j$ párokat véletlenszerüen választjuk ki, minden kereskedőnek egyenlő esélye van arra, hogy kiválasztásra kerüljön. Az ügylet lejárata lehet $T_{1}$ vagy $T_{2}$. Az első lejárat valószínüsége $p_{t}$ a $T_{1}$-ig hátralévő idő növekvő függvénye. (Ebből következik, hogy $1-p_{t}$ a második lejárat valószínűsége.)

Az $A_{t, d}^{m, k}$ jelöli a $d$-edik $\left(d=1, \ldots, D_{t}^{m}\right)$ ügylet nagyságát a $t$-edik napon az $m$-edik részvényben a $k$-adik lejáratra. Az $n$-edik kereskedő pozíciója $(P)$ (darabszámban és elöjelesen megadva) a következö képlet szerint alakul ki:

ha $n=i$, akkor $P_{t, d}^{n, m, k}=A_{t, d}^{m, k}$,

ha $n=j$, akkor $P_{t, d}^{n, m, k}=-A_{t, d}^{m, k}$,

különben

$P_{t, d}^{n, m, k}=0$.

Számos, különböző tulajdonságú (a részvény típusa, vétel vagy eladás, az ügylet nagysága és lejárata) ügylet szimulációját követően meghatározzuk az $n$-edik kereskedő $m$-edik részvényben a $t$-edik napon a $k$-adik lejáratra fennálló nettó

\footnotetext{
${ }^{4}$ Mivel az azonnali piacok $t+2$ napos elszámolási rendszerben működnek, az azonnali piacok nagyon rövid lejárattal rendelkező határidős piacoknak is tekinthetők.
} 
felhalmozódott kitettségét (E) (ugyancsak darabszámban és előjelesen megadva) a következők alapján:

$$
\begin{aligned}
& E_{t}^{n, m, k}=E_{t-1}^{n, m, k}+\sum_{d=1}^{D_{t}^{m}} P_{t, d}^{n, m, k} . \\
& E_{0}^{n, m, k}=0 .
\end{aligned}
$$

Az adott ügyfélre vonatkozó, ellenkező előjelü, egy termékre és lejáratra szóló pozíciók kioltják egymást, mivel a long és short oldali pozíciók eredője nulla.

Az $n$-edik kereskedö letéti követelményének $(R)$ meghatározására a $t$-edik nap végén kerül sor, és a következő napra vonatkozik. A letéti követelmény a kereskedő teljes portfóliójának $\left(E_{t}^{n}\right)$ kockázatott értéke $(V a R)$, ahol a visszatekintési időszak $w=1$ év, a tartási periódus $\tau=2$ nap, a szignifikanciaszint pedig $\alpha=99$ százalék. ${ }^{5}$

$R_{t}^{n}=\operatorname{VaR}\left(E_{t}^{n}, w, \tau, \alpha\right)$.

A portfólió kockáztatott értékét a historikus módszerrel határozzuk meg. Feltétezzük, hogy ezenfelül nincs semmiféle extrakövetelmény, azaz a kiegészítő módszerektől (stresszteszt, forgatókönyv-elemzés) eltekintünk. $R_{0}^{n}-\mathrm{t}$ - az $n$-edik szereplö kezdeti letétét - az egyszerűség kedvéért nullára állítjuk.

$\mathrm{Az} n$-edik kereskedő letéti számlája (C) (margin account) a $t$-edik napon az egyes részvényekhez és lejáratokhoz tartozó letétek összessége, amely mindennap változik a napi elszámolásnak köszönhetően:

$$
\begin{aligned}
& C_{t}^{n}=C_{t-1}^{n}-T_{t}+\sum_{m=1}^{M} \sum_{k=1}^{2} E_{t}^{n, m, k} \cdot\left(F_{t}^{m, k}-F_{t-1}^{m, k}\right), \\
& C_{0}^{n}=R_{0}^{n},
\end{aligned}
$$

ahol $T_{t}$ a $t$-edik napon a számláról levett nyereség, az ügyfél döntési változója. $\mathrm{E}$ tekintetben két szélsőségesen különböző stratégiát vizsgálunk (a valóság valahol a kettő között lehet):

1. lejáratig sohasem veszik ki a felhalmozódott nyereséget a számlájukról (Semmit nem vesz ki);

2. a képződött nyereséget azonnal kiveszik a számlájukról (Mindent kivesz).

Vegyük észre, hogy a Semmit nem vesz ki stratégia útvonalfüggőséget visz a rendszerbe, hiszen a rendelkezésre álló fedezet nagysága attól függ, hogy a múltban menynyire volt nyereséges a pozíció. ${ }^{6}$

Ha az $n$-edik kereskedő letéti számlája kisebb, mint a nap végén kalkulált követelmény, azaz

$R_{t}^{n}>C_{t}^{n}$,

\footnotetext{
${ }^{5}$ A visszatekintési időszak, a likvidációs időszak és a szignifikancia-paraméterek a tőzsdei ügyletek EMIR által meghatározott értékei, amelyek megfelelnek a modellben feltett likvidációs időszaknak is.

${ }^{6}$ Megjegyezzük, hogy a tőzsdén kívüli származtatott termékek esetében a nyereségeket/veszteségeket nem számolják el naponta, csupán a veszteség fedezéséhez szükséges letéteket kérik be, ami a Semmit nem vesz ki stratégiának felel meg.
} 
akkor az elszámolóház küld egy letétfeltöltési felszólítást, amelyben megkéri az ügyfelet, hogy másnap reggelig töltse fel a letéti számláját a követelménynek megfelelő szintig. Előfordulhat, hogy a kereskedő nem tesz eleget ennek a felszólításnak. A nemfizetés valószínűségét $\left(q_{t}^{n}\right)$ a szimuláció során 1-re állítottuk. Ekkor az elszámolóház lezárja a pozíciót a következő napi záró árfolyamon. Ez a zárás a piaci árfolyamok függvényében veszteséges is lehet.

Az elszámolóház veszteségét $(L)$ a $t$-edik napon az egyes kereskedőkön elszenvedett veszteségek összegeként határozzuk meg:

$L_{t}=\sum_{n=1}^{N} L_{t}^{n}=-\sum_{n=1}^{N} q_{t}^{n} \times \min \left\{C_{t}^{n}+E_{t}^{n, m, k}\left(F_{t}^{m, k}-F_{t-1}^{m, k}\right) ; 0\right\}$.

A következőkben azt vizsgáljuk, hogy az amerikai részvénypiacon miképpen alakult volna ennek a hipotetikus elszámolóháznak a pozíciója, majd összehasonlítjuk a veszteségek mértékét és időbeliségét néhány piaci stresszváltozó alakulásával.

\section{Az elszámolóház vesztesége}

Az előzőkben ismertetett módon szimuláltuk egy, az amerikai határidős részvénypiacon aktív hipotetikus elszámolóház müködését 2007 és 2015 között. A kereskedők véletlenszerű tranzakciói alapján kialakuló kitettség 100 lehetséges realizációját vizsgáltuk. A kereskedett eszköz az S\&P100 volt, minden realizációban meghatároztuk a napi veszteség/kitettség mutatót, ahol a veszteséget dollárban, a kitettséget pedig a nyitott pozíciók számában határoztuk meg. Az 1. ábra mutatja az átlagos veszteség/kitettség mutatók értékét a nyolc év során a Semmit nem vesz $k i$ és a Mindent kivesz stratégia mellett.

Ahogy várható volt, a veszteségek mérete lényegesen nagyobb abban az esetben, amikor a klíringtagok minden nyereséget azonnal kivesznek, de a veszteségek időzítése megegyezik a két stratégia esetén. Az is látható, hogy a vizsgált nyolc évben körülbelül hét jelentősebb stresszesemény következett be, így a következő hét stresszidőszakot azonosítottuk. A dátumok és a legvalószínübb kiváltó események a következők:

1. 2008. március 19-20. - a jelzáloghitel-válság elöszele,

2. 2008. szeptember-október - a Lehman Brothers csődje,

3. 2010. május 11. - „Flash Crash”, azaz az algoritmizált kereskedés (high frequency trading) átmeneti zavara,

4. 2011. augusztus 5-19. - fokozódó államadósság-válság az európai országokban és sorozatos leminősítések,

5. 2014. augusztus 1. - növekvő geopolitikai fenyegetettség (Ukrajna-Oroszország, Egyesült Államok-ISIS stb.) és a magas hozamú kötvénypiacok összeomlása,

6. 2014. december 19. - orosz válság,

7. 2015. augusztus 21-27. - kínai válság.

Látható, hogy a legnagyobb veszteségeket a Lehman bukása (2008), az európai hitelválság (2011) és a nemrégiben történt kínai válság (2015) okozta. 
1. ábra

Az elszámolóház veszteség/kitettség mutatója, 2007-2015

Veszteség dollárban/nyitott pozíciók száma

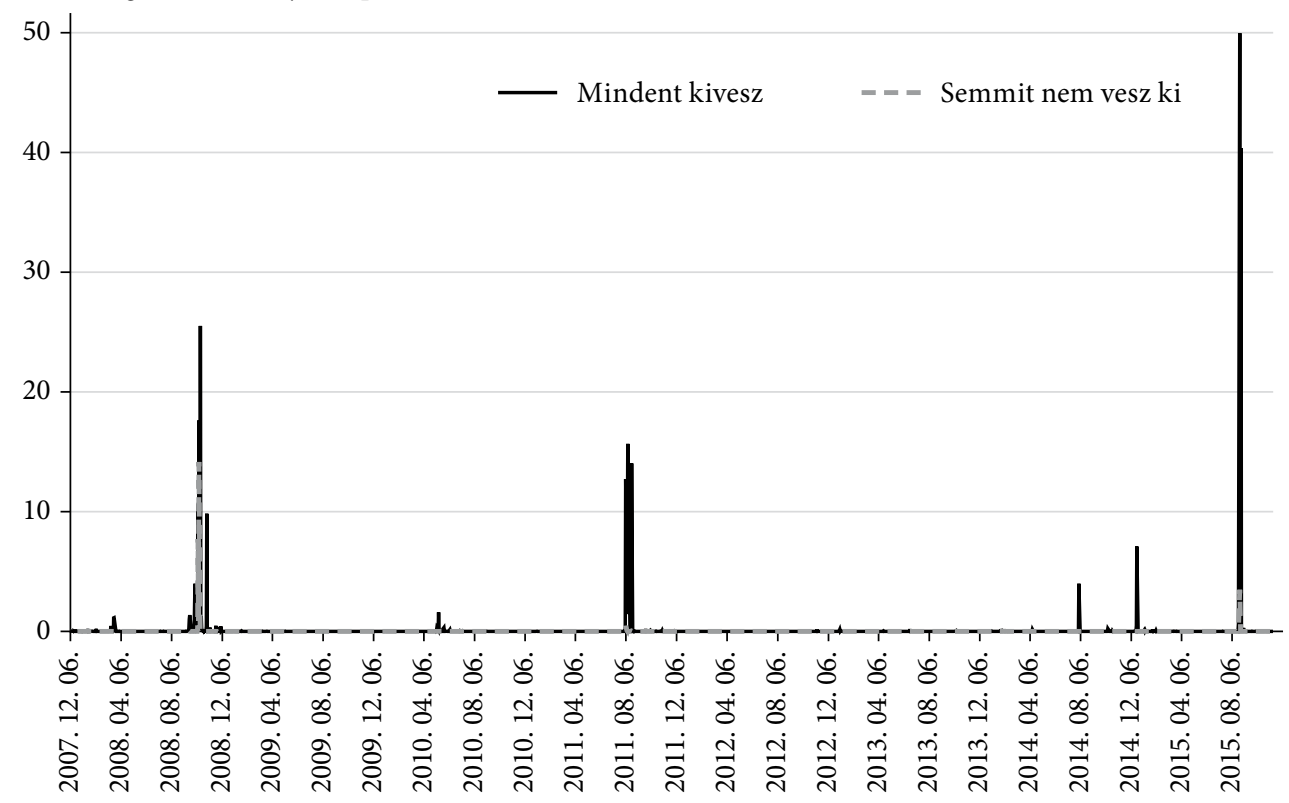

Forrás: saját szerkesztés.

\section{Stresszmutatók}

A szabályozás szerint az elszámolóház kockázatkezelésében kulcsszerepet játszó stressz fogalma alapulhat a kockázatkezelési bizottság aktuális szakértői véleményén (szubjektív módszer) vagy konkrét, előre definiált kritériumok alkalmazásán (objektív módszer). Mindkét módszer esetén felügyeletei engedély szükséges, azonban az előbbi esetben egyenként minden döntést jóvá kell hagyatni a felügyeletnél, míg utóbbi esetben elég egyszer engedélyeztetni a modellt.

Az objektív módszer esetében a kritérium lehet endogén, amely az elszámolóházak kockázatkezelési rendszerén alapul, például:

- a kockáztatott érték (VaR) vagy egyéb kockázati mérték átlépése;

- letéti követelményre vonatkozó feltöltési felszólítás;

- nemfizetés a felszólítást követően;

- a garanciaalap lehívása stb.

Elképzelhető azonban, hogy az elszámolóházak vagy a szabályozó előnyben részesít egy egzakt, külső adatokon alapuló, tehát exogén stresszmeghatározást. Ebben az esetben is legalább két lehetőség létezik:

- egy harmadik szereplő (szabályozó vagy egyéb intézmény) által meghatározott, előregyártott, külső stresszindex alkalmazása; vagy 
- az elszámolóházra szabott, egyedi stresszmodell kialakítása, amely az elszámolóház speciális igényeihez igazodik.

A következőkben ez utóbbi két lehetőséget vizsgáljuk meg részletesen.

\section{Elöregyártott, külső stresszindex}

Egy exogén stresszmutató kiválasztásakor magától értetődőnek tủnik egy általános piaci stresszindex használata. Számos pénzügyi stresszmutatót javasol az irodalom, ${ }^{7}$ amelyek célja, hogy egy átfogó piaci stressz bekövetkeztét jelezzék. Ezek mellett léteznek olyan mutatók is, amelyek csak meghatározott szempontból mérik a stresszt, például a befektetők kockázati étvágyában bekövetkezö változást (Kumar-Persaud [2001]), vagy egy konkrét piacot, például a bankszektort érő negatív hatásokat (Carlson és szerzötársai [2011]).

Az egyes stresszmodellek teljesítményének vizsgálatát logisztikus regressziós modell segítségével végeztük. ${ }^{8}$ Azt vizsgáltuk, hogy a különbözö változók mennyiben magyarázzák az általunk szimulált elszámolóház veszteségeit.

\section{Testre szabott stresszmodell}

Egy hatékonyabb, az általunk szimulált elszámolóház jellemzőihez szabott stresszmodell felépítéséhez érdemes megvizsgálni azokat a piaci tényezőket, amelyek általában a pénzügyi stressz közelítő változóinak (proxy) tekinthetők.

- PIACI TREND: S\&P100 NAPI LOG(HOZAM) • Bármely irányú extrém ármozgás piaci turbulenciát jelezhet az elszámolóház számára, amit a log(hozam)-mal, azaz a napi árak logaritmikus megváltozásával számszerüsítünk.

- PIACI BIZONYTALANSÁG ÉS BEFEKTETŐI KOCKÁZATI ÉTVÁGY: VIX-INDEX • A chicagói tőzsde (CBOE) vezette be 1993-ban a volatilitásindexet (Volatility Index, VIX) a rövid lejáratú eszközök volatilitásának mérésére. Számítása az S\&P500 részvényindexre szóló opciók árai alapján történik. A VIX-et napi szinten határozzák meg, a befektetők számára ez a legfontosabb, a piaci bizonytalanságot és a befektetői kockázatérzékenységet tükröző mérőszám.

- FinANSzírozÁsi likviditás: US 3M Libor mínUsz OIS • A kötvénypiacon a Libor (London Interbank Offered Rate, Libor) és az OIS (Overnight Indexed Swap) különbsége lényegében a hitelkockázat egyik méröszáma. A Libor a fedezetlen hitelek kamatlába, míg az OIS egy olyan csereügylet (swap), amely csak minimális partnerkockázatot hordoz, mivel a névértéket nem cserélik el a felek az ügylet folyamán. A Libor - OIS különbözet nulla közeli értéket vesz fel normális piaci körülmények között, válság idején azonban több százalékra is felugorhat az értéke, ami a finanszírozási forrásokhoz való hozzájutás nehézségét mutatja.

\footnotetext{
${ }^{7}$ Például a következők: Hakkio-Keeton [2009]: Kansas City Financial Stress Index (KCFSI); IllingLiu [2006]: Financial Stress Indicator of Canada (FSI); Hollo és szerzőtársai [2012]: Composite Indicator of Systemic Stress (CISS); vagy Bordo és szerzőtársai [2002]: Financial Stability Index.

${ }^{8}$ A módszertan leírásához lásd Kovács [2009].
} 
- Piaci likviditás: S\&P-ÁRfolyam-KülönbÖZet • A piaci likviditás leginkább elfogadott méröszáma a legjobb vételi és eladási ár közötti különbség $(d)$. Egy csak elméletben létező, tökéletesen súrlódásmentes piacon a különbözet értéke nulla lenne.

A fentiekben bemutatott stresszváltozók időbeli alakulását mutatja a 2. ábra. A függőleges vonalak a modell veszteségadatai alapján meghatározott hét stresszidőszakot jelölik.

2. ábra

a) Piaci trend - S\&P100 napi $\log ($ hozam)

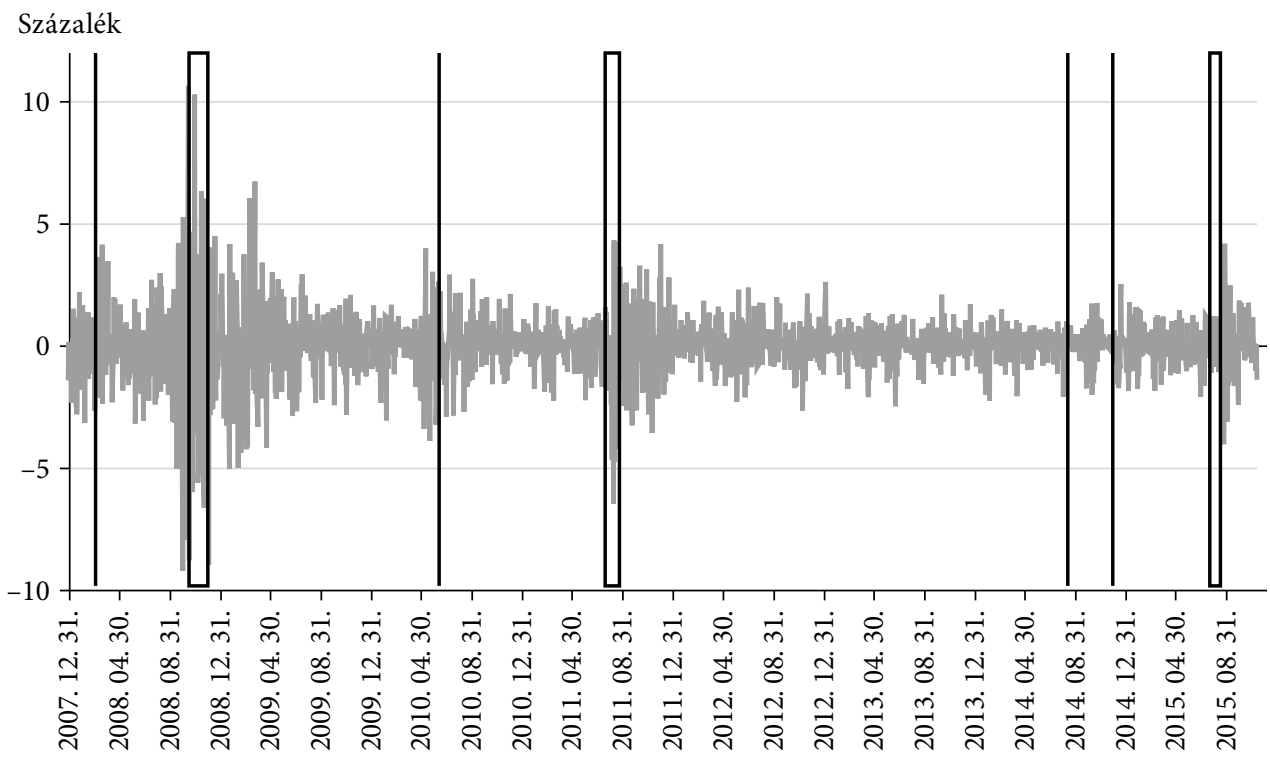

b) Bizonytalanság és kockázati étvágy - VIX-index

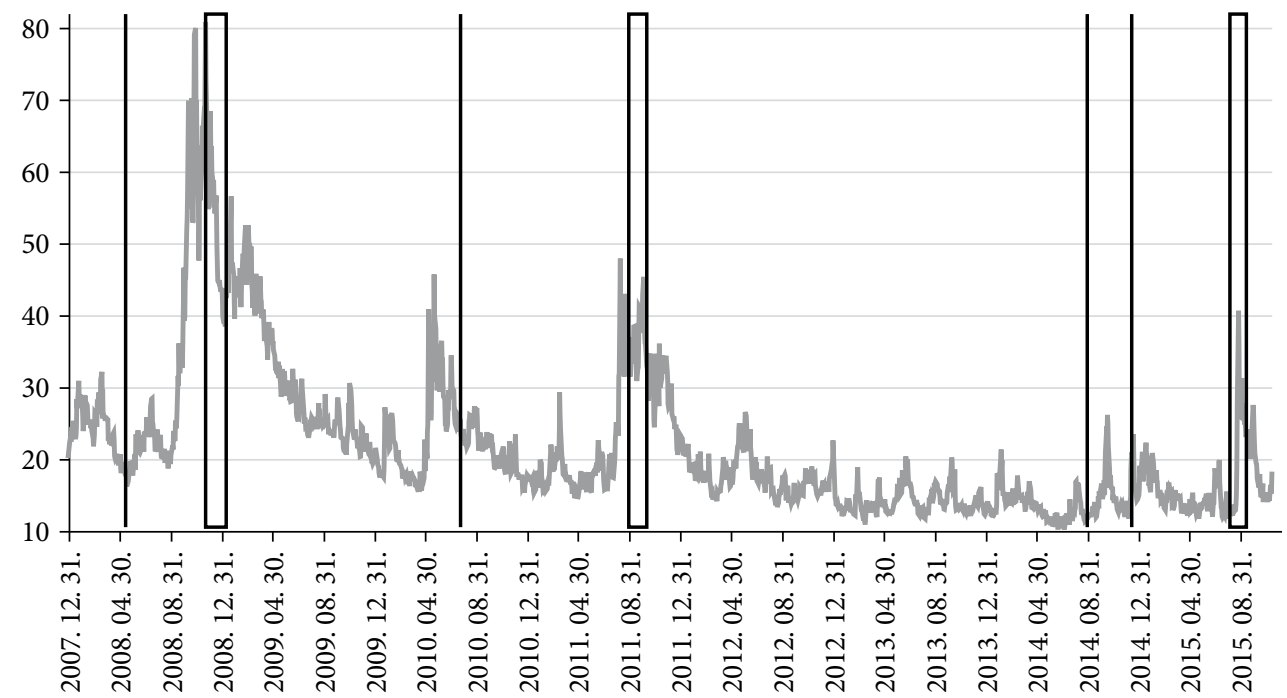


c) Finanszírozási likviditás - US 3M Libor mínusz OIS

Százalék

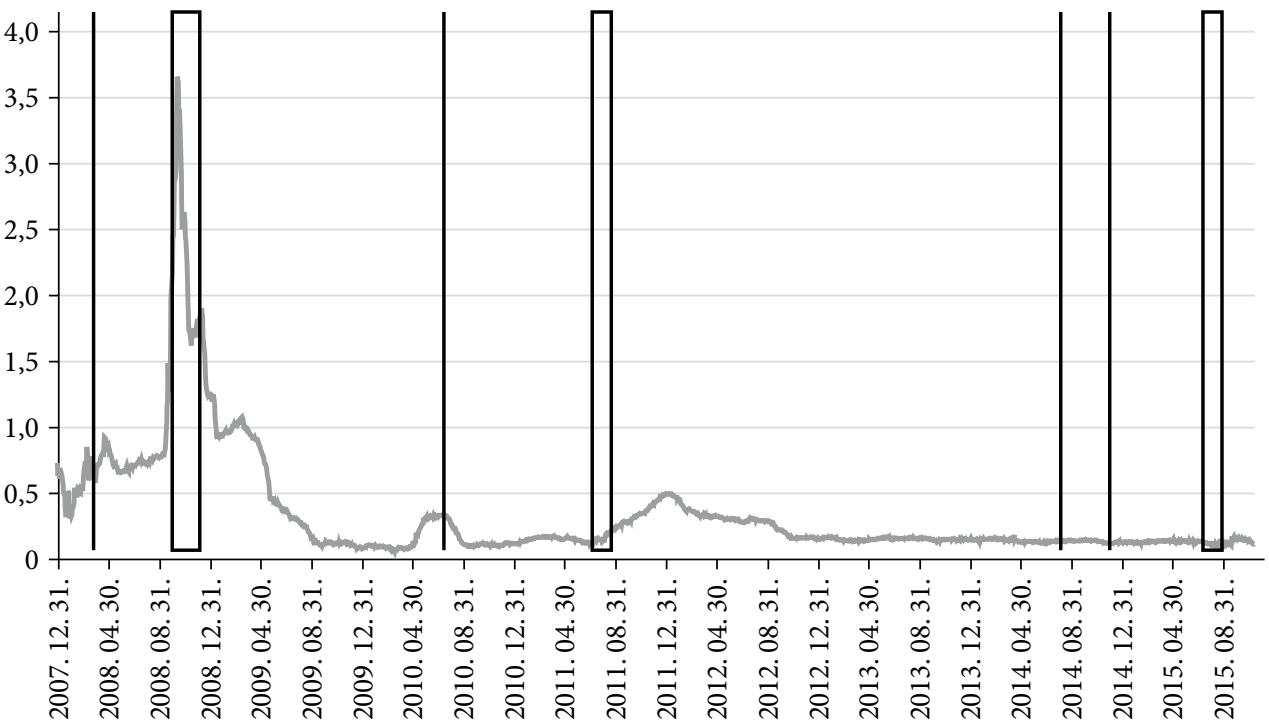

d) Piaci likviditás - S\&P500-árfolyam-különbözet

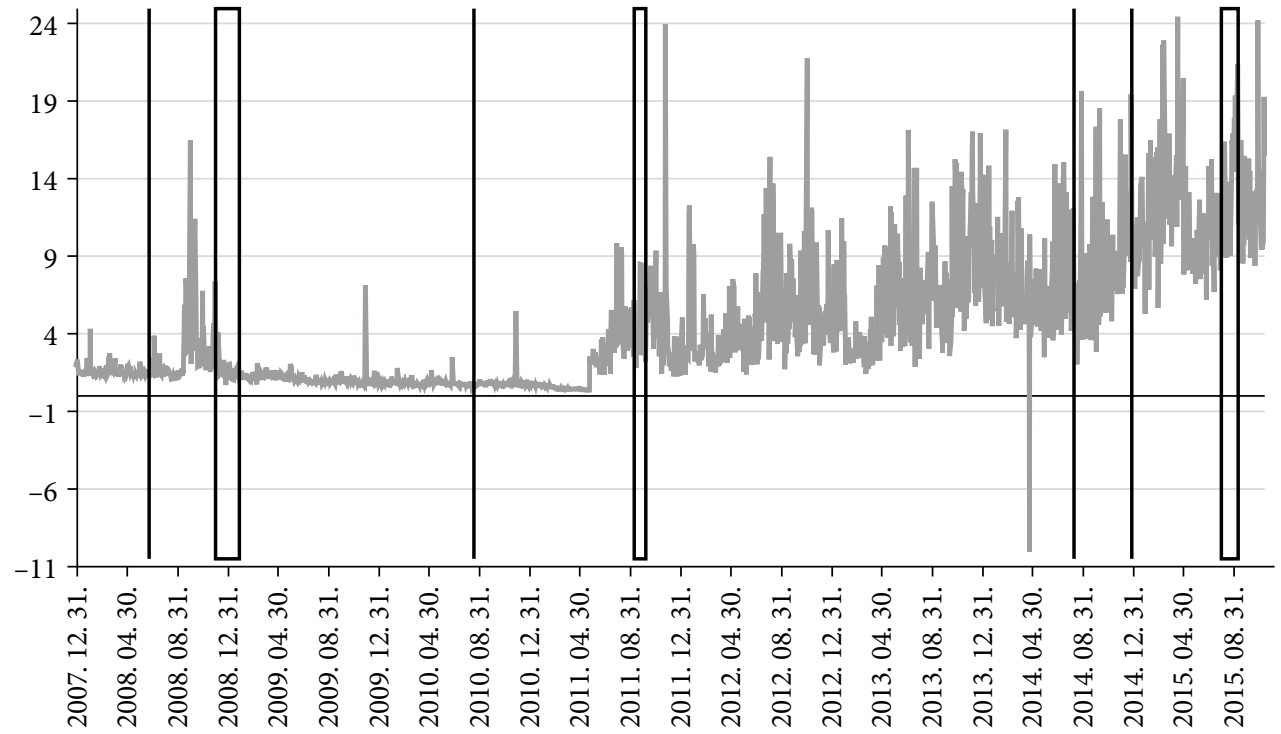

Megjegyzés: a függőleges vonalak a modell veszteségadatai alapján meghatározott hét stresszidőszakot jelölik (a legvalószínűbb kiváltó események: 2008. március 19-20.: a jelzáloghitelválság előszele, 2008. szeptember-október: a Lehman Brothers, 2010. május 11.: Flash Crash, 2011. augusztus 5-19.: államadósság-válságok Európában, 2014. augusztus 1.: növekvő geopolitikai fenyegetettség és a magas hozamú kötvénypiacok összeomlása, 2014. december 19.: orosz válság, 2015. augusztus 21-27.: kínai válság).

Forrás: saját szerkesztés. 
Az ábrákon is jól látható, hogy bár a piaci gyakorlatban használatos pénzügyi stresszfaktorok mind egymással, mind pedig az elszámolóház veszteségeivel együtt mozognak, nem minden stresszidőszakot jeleztek egyformán az egyes változók. A Lehman-válság egy klasszikus válság abban az értelemben, hogy mindegyik stresszmutató egyszerre jelzett. A legutóbbi jelentős válság (kínai válság) ideje alatt viszont a finanszírozási likviditás és a piaci likviditás nem mutatott a megszokottól jelentősen eltérö piaci helyzetet.

Az egyes stresszmutatók egymással és a generált veszteségekkel számított korrelációját mutatja az 1. táblázat.

\section{1. táblázat}

A piaci stresszmutatók és a veszteségek korrelációja

\begin{tabular}{lcccccc}
\hline & $\begin{array}{c}\text { S\&P- } \\
\text { árfolyam- } \\
\text { különbözet }\end{array}$ & VIX-index & $\begin{array}{c}\text { US 3M } \\
\text { Libor - OIS }\end{array}$ & Log(hozam) & $\begin{array}{c}\text { Mindent } \\
\text { kivesz }\end{array}$ & $\begin{array}{c}\text { Semmit } \\
n e m \text { vesz } k i\end{array}$ \\
\hline $\begin{array}{l}\text { S\&P-árfolyam- } \\
\text { különbözet }\end{array}$ & 1,00 & $-0,32$ & $-0,21$ & 0,75 & 0,08 & 0,05 \\
VIX-index & $-0,32$ & 1,00 & 0,77 & $-0,67$ & 0,15 & 0,15 \\
US 3M Libor - OIS & $-0,21$ & 0,77 & 1,00 & $-0,42$ & 0,13 & 0,22 \\
Log(hozam) & 0,75 & $-0,67$ & $-0,42$ & 1,00 & $-0,01$ & $-0,03$ \\
Mindent kivesz & 0,08 & 0,15 & 0,13 & $-0,01$ & 1,00 & 0,39 \\
Semmit nem vesz ki & 0,05 & 0,15 & 0,22 & $-0,03$ & 0,39 & 1,00 \\
\hline
\end{tabular}

Forrás: saját szerkesztés.

A napi adatok alapján az látjuk, hogy az elszámolóházi veszteségek alig korrelálnak a piaci stresszmutatókkal. Ennek egyik magyarázata az lehet, hogy veszteségek gyakran csak késleltetve jelentkeznek, vagyis akkor, amikor a piaci stressz már egy ideje fennáll. Másrészt az egyes mutatók különféle piaci turbulenciát mérnek, így az együttes hatásuk a meghatározó az elszámolóház veszteségeinek szempontjából.

$\mathrm{Az}$ adott intézmény tevékenységére szabott saját modell meghatározásánál ezért a fenti mutatók mint magyarázó változók segítségével egy logisztikus regressziós modellt építettünk. A modell függő változója azt mutatja, hogy van-e stressz, vagy nincs. Elemzésünkben a bekövetkezett stressznek a szimulált veszteségek legrosszabb 10 százalékát választottuk.

\section{Eredmények}

A modellek magyarázó erejét ROC (Receiver Operating Characteristic) diagnosztikai görbével és Gini-mutatóval mértük. Ha a modellnek nincs magyarázó ereje, akkor a ROC-görbe pontjai közel lesznek az átlóhoz, míg tökéletes osztályozás esetén a görbe érinti a bal felsö sarkot. 
Az 1. modellben egy előregyártott, külső stresszindex teljesítményét vizsgáltuk, ahol magyarázó változónak a clevelandi pénzügyi stresszindexet (Cleveland Financial Stress Index, CFSI) választottuk. ${ }^{9}$ Hasonlóan a többi általános stresszindexhez, a CFSI is többféle változót tartalmaz, amelyek a pénzügyi rendszer különböző szegmenseiben zajló folyamatokat tükrözik, és ezeket egyetlen értékbe tömörítve számszerüsítik a piac általános állapotát (3. ábra).

\section{3. ábra}

Az 1. modell ROC-görbéje - magyarázó változó: Cleveland Financial Stress Index (CFSI)

a) Mindent kivesz

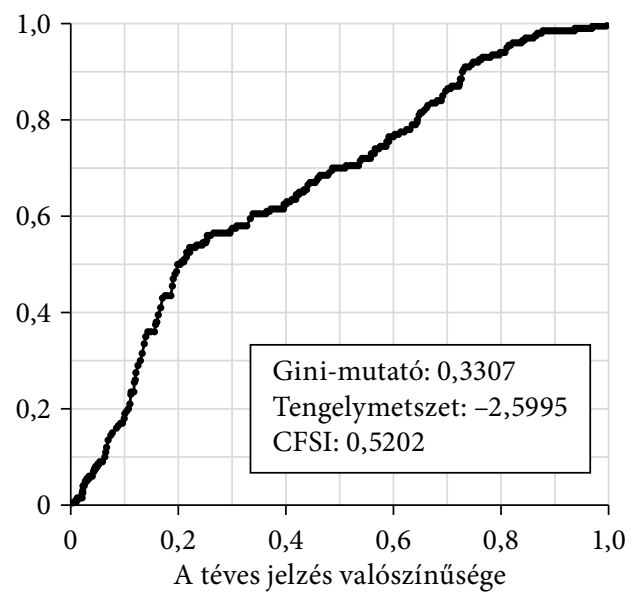

b) Semmit nem vesz ki

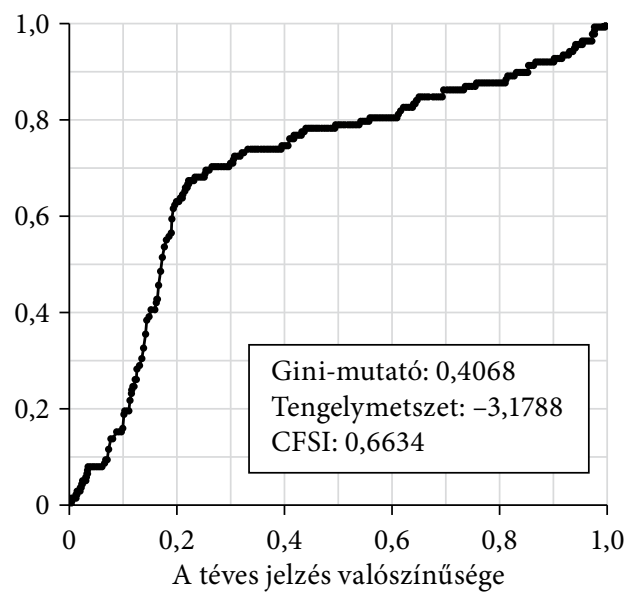

Forrás: saját szerkesztés.

A CFSI négy pénzügyi szektor, a kötvénypiac, a részvénypiac, a devizapiac és a bankközi piac összesen 11 változójának napi értékeiből tevődik össze. Az 1. modell Giniegyütthatója 0,33 és 0,41 , tehát a modell magyarázó ereje közepesnek tekinthető. Érdekes, hogy a kevésbé direkt, útvonalfüggö Semmit nem vesz ki eset mellett a modell kicsit jobban teljesített. Ez azért meglepő, mert a Semmit nem vesz ki esetben nemcsak az aktuális piaci eseményektől függ a veszteség, hanem attól is, hogy a megelöző időszakban a klíringpartner pozíciói nyereségesek voltak-e, ami pusztán a jelenlegi adatok alapján nehezítheti a stressz korrekt meghatározását. Továbbá azonban nyilvánvaló, hogy a Semmit nem vesz ki stratégiában az ügyfelek átlagos fedezete magasabb, ami csökkenti a veszteségek mértékét. A két hatás eredőjétől függ, hogy az adott modell melyik stratégia mellett bizonyul jobbnak a stressz azonosítása terén.

Mivel az általunk vizsgált elszámolóház tevékenysége kizárólag a részvénypiacra vonatkozik, érdemes megvizsgálni, hogy a CFSI index részvénykomponensének (Equity Contributor: Stock Market Crashes) magyarázó ereje önmagában nagyobb-e, mint egy általános index részeként (2. modell - 4. ábra).

\footnotetext{
${ }^{9}$ Az adatokat 2015. november 28-án töltöttük fel a https://research.stlouisfed.org/fred2/series/ CFSI\# oldalról.
} 
4. ábra

A 2. modell ROC-görbéje - magyarázó változó: CFSI Equity Contributor (EQMRK)

a) Mindent kivesz

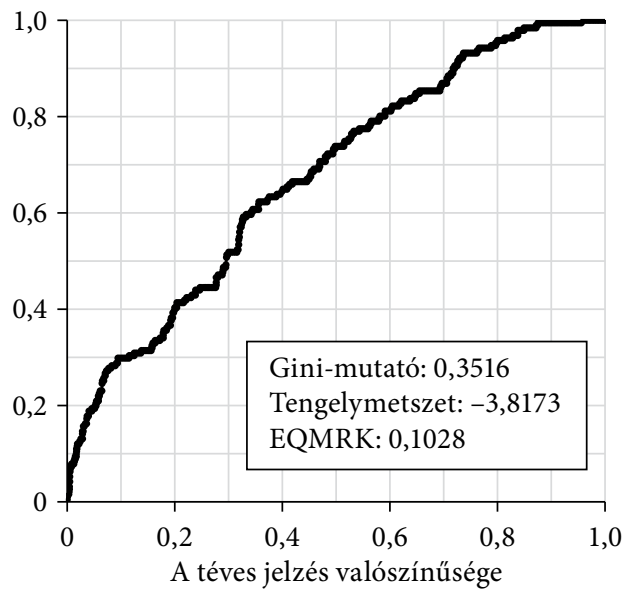

b) Semmit nem vesz ki

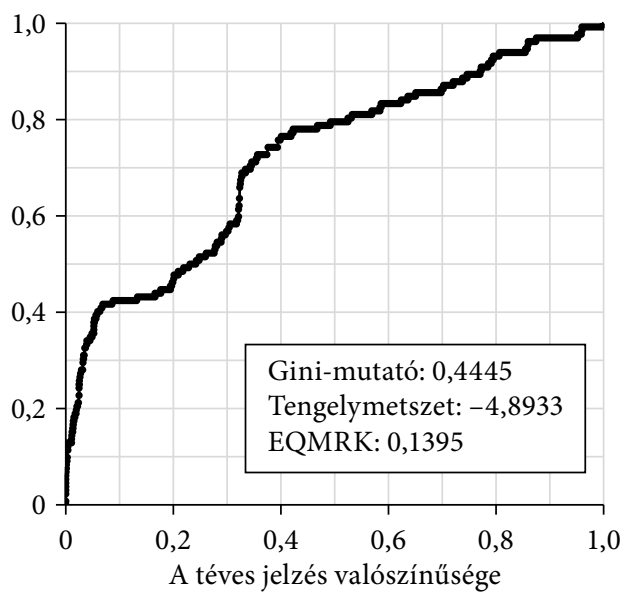

Forrás: saját szerkesztés.

Ahogy várható volt, a Gini-mutató szerint a 2. modell általában jobban teljesít, mint az általános 1 . modell (0,52 és 0,66 szemben a 0,35 és 0,44 értékekkel), de a javulás nem számottevő. Ha megvizsgáljuk a ROC-görbéket, akkor azt látjuk, hogy 10 százalékos téves riasztás (másodfajú hiba) mellett a stresszes időszakoknak körülbelül a 20 százalékát sikerült jól beazonosítani az 1. modellel, míg 30-40 százalékát a 2. modellel. Ezzel szemben 20 százalékos másodfajú hibát megengedve, az 1. modell érzékenysége a nagyobb, hiszen ott a találati arány 50-60 százalék, szemben a 2. modell 40-45 százalékos értékeivel. Így, bár azt várnánk, hogy egy részvénypiaci stresszindex jobban illeszkedik egy olyan elszámolóház kockázati profiljához, amely csupán a részvénypiacon aktív, számottevő eredményt nem sikerült elérni, sőt bizonyos szempontból romlott az előre jelző modell hatékonysága. Hogy végső soron melyiket érdemes választani a kettő közül, az föként az első és a másodfajú hibával kapcsolatos döntésünk függvénye.

A következőkben megvizsgáljuk, hogy a modell javítható-e az elszámolóház további specialitásainak figyelembevételével.

Az elszámolóház müködési elvéből következik, hogy a veszteségek fö oka az árfolyam szélsőséges megváltozása. E kapcsolat vizsgálatára egy újabb logit regressziós modellt írtunk fel (3. modell), ahol az S\&P100 log(hozam) az egyetlen magyarázó változó (5. ábra).

Az 5. ábrán látható, hogy önmagában a log(hozam) magyarázó ereje alacsony, hiszen a Gini-együtthatók értékei sokkal kisebbek, mint az elöző modellekben. Ráadásul, a ROC-görbéken felfedezhető $S$ alak azt mutatja, hogy a függő változó (veszteség) valószínüleg nem monoton függvénye a $\log ($ hozam)-nak. Mivel az elszámolóház veszteségei inkább függnek az árváltozás nagyságától, mintsem az 
5. ábra

A 3. modell ROC-görbéje - magyarázó változó: log(hozam)

a) Mindent kivesz

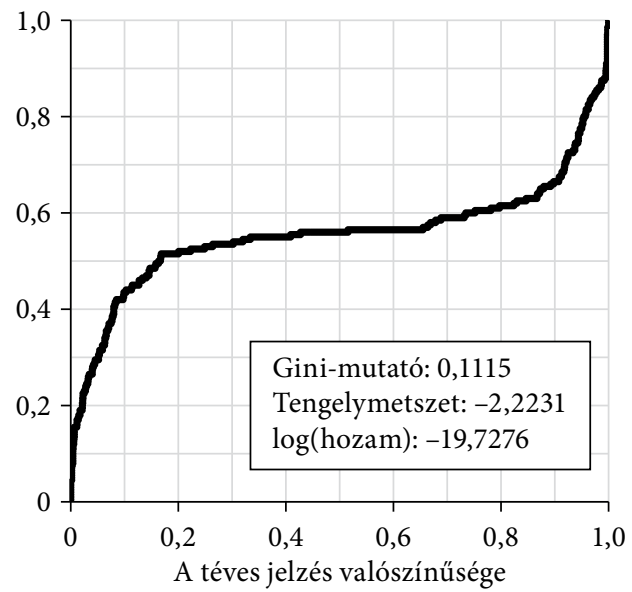

b) Semmit nem vesz ki

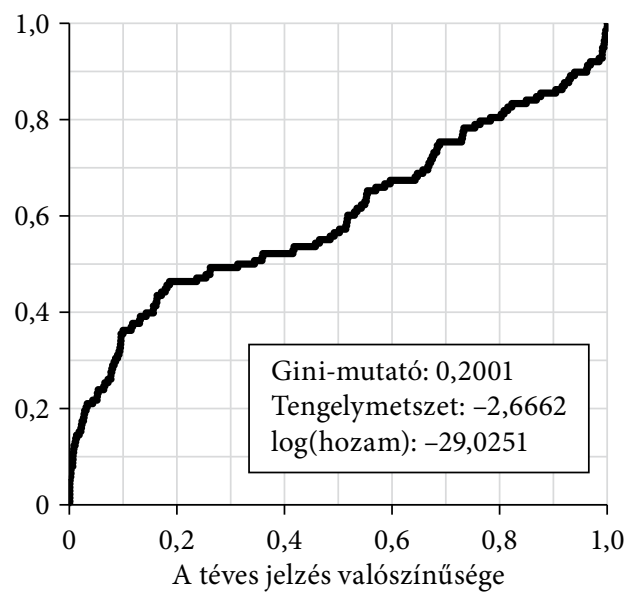

Forrás: saját szerkesztés.

irányától (köszönhetően a szimmetrikus kitettségnek), érdemesebb a log(hozam) abszolút értékét választani magyarázó változónak.

A 4. modellben a log(hozam) abszolút értéke mint magyarázó változó látványosan jobb modellt eredményez a Mindent kivesz stratégia mellett, hiszen a Gini-együttható 0,7-re nőtt (6. ábra). Ebből is látható, hogy az aktuális árváltozás mértéke és az elszámolóház vesztesége közötti kapcsolat erös. Figyelembe kell azonban vennünk, hogy valójában nem is az árváltozás mértéke a lényeges, hanem annak a meglepetés jellege, vagyis az a része, amire a letéti követelményt meghatározó kockázati modellek nincsenek felkészülve. Megfigyelhető az is, hogy a Semmit nem vesz ki stratégia mellett a biztosíték aktuális értékére a múltbeli ármozgások is hatnak, ezért a veszteségeket nemcsak az aktuális ármozgások, hanem a régebbiek is befolyásolják. Ez lehet az oka, hogy ebben az esetben a 4 . modell sokkal rosszabbul teljesít.

Megnéztük, hogy a modell továbbfejleszthető-e más stresszel kapcsolatos piaci tényezők bevonásával. Az 5. modellbe az összes 1. táblázatbeli stresszmutatót beépítettük (7. ábra).

Láthatjuk, hogy messze ez a legjobb modell az összes vizsgált modell közül. Ahogy vártuk, némileg jobban teljesít a Mindent kivesz esetben: a Gini-együttható 0,76-os értéke, valamint 10 százalékos másodfajú hiba mellett a stresszidőszakok mintegy 65 százalékát sikerült azonosítani, 20 százalékos téves besorolás mellett pedig már 80 százalékhoz közeli a találati arány. A Semmit nem vesz ki eset is csak kismértékben teljesít rosszabbul (Gini-együttható = 0,62). Mindegyik magyarázó változó szignifikáns 99,9 százalékos szinten, kivéve a Libort, ami csak 99 százalék mindkét esetben.

Összességében tehát megállapítható, hogy az 5. modellhez hasonló belső modell lehet a megfelelö módszer egy személyre szabott, de mégis objektív stresszdefiníció 
6. ábra

A 4. modell ROC-görbéje - magyarázó változó: abslog(hozam)

a) Mindent kivesz

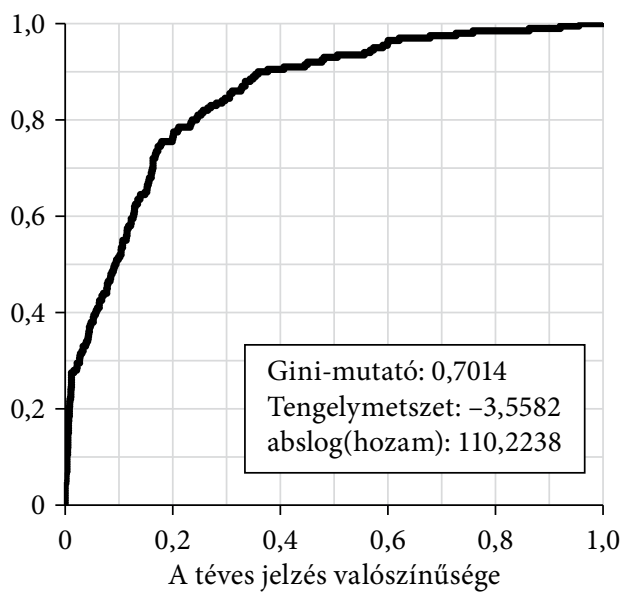

b) Semmit nem vesz ki

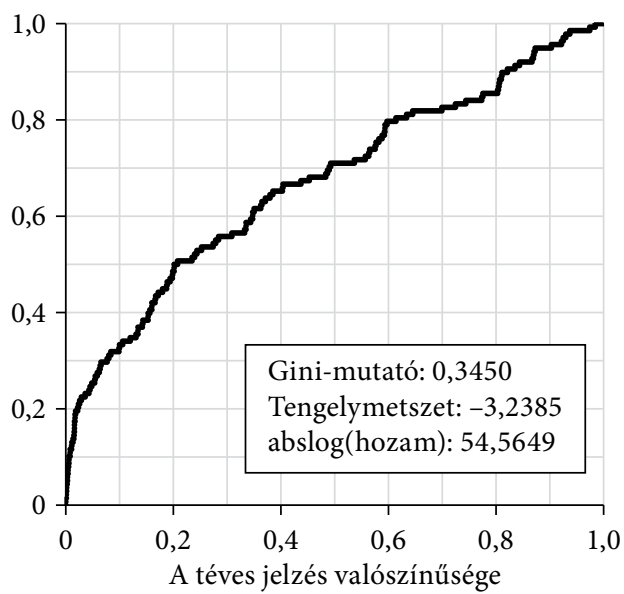

Forrás: saját szerkesztés.

\section{7. ábra}

Az 5. modell ROC-görbéje - magyarázó változók: abslog (hozam), VIX-index, Libor 3M, OIS, S\&P-árfolyam-különbözet

a) Mindent kivesz

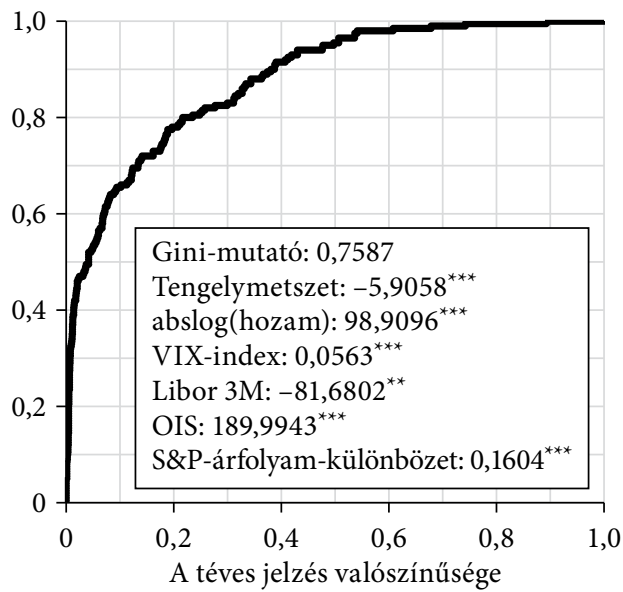

b) Semmit nem vesz ki

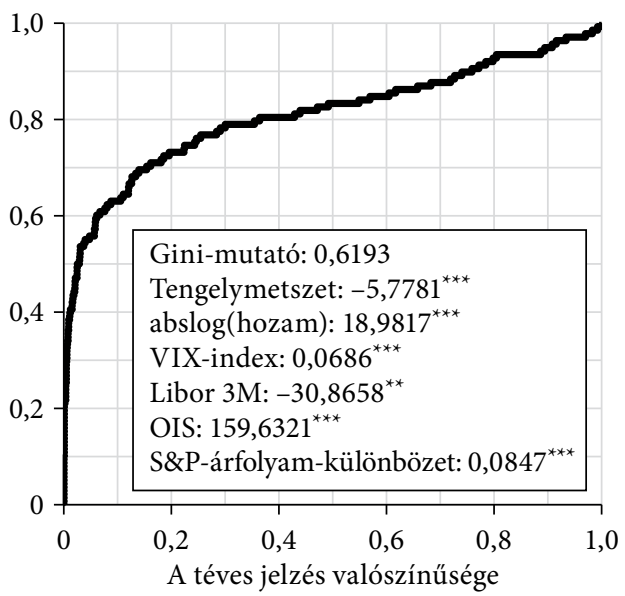

${ }^{\star * *} 1$ százalékos szinten, ${ }^{\star *} 5$ százalékos szinten, ${ }^{\star} 10$ százalékos szinten szignifikáns értékek. Forrás: saját szerkesztés.

kialakításakor. Figyelembe kell venni azonban, hogy a többváltozós regressziós modell magyarázó változói közötti multikollinearitás (lásd 1. táblázat) ronthatja a modell megbízhatóságát. A megfigyelések számának növelésével azonban csökken ennek a problémának a jelentősége. 


\section{Összefoglalás}

A legújabb pénzügyi piaci szabályozási változásoknak köszönhetően a központi elszámolás jelentősége egyre növekszik. Ebben a cikkben azt vizsgáltuk, hogy az elszámolóház veszteségei milyen összefüggésben vannak egyes piaci stresszfaktorokkal.

Először egy hipotetikus elszámolóház működését modelleztük, és és veszteségeket szimuláltunk az amerikai határidős részvénypiacon véletlenszerűen alakuló kereskedésből származó kitettségek alapján, az elmúlt nyolc év árfolyamadatainak felhasználásával. A szimuláció segítségével hét nagyobb stresszeseményt azonosítottunk ezen időszak alatt.

Második lépésben megnéztük a kapcsolatot az elszámolóház szimulált veszteségei és egy általános amerikai piaci stresszindex (CFSI) között. Azt találtuk, hogy az elszámolóház sebezhetősége és az általános stresszindex közötti kapcsolat közepes erősségü. Ebből arra következtettünk, hogy a külső „előregyártott” stresszindex helyett érdemes áttérni egy saját többváltozós modellre, amelybe az egyes stressztényezőket egyenként építjük be.

Néhány kísérlet után egy saját magunk által készített többváltozós modellhez jutottunk (5. modell), amely sokkal jobban teljesített akkor is, ha a klíringtagok minden képződött nyereséget azonnal kivettek a számlájukról (Mindent kivesz stratégia), és abban az esetben is, amikor mindent bennhagytak a számlájukon (Semmit nem vesz ki stratégia). Nem meglepő módon a legfontosabb magyarázó változó a $\log ($ hozam) volt, de mivel az elszámolóház kitettsége szimmetrikus, a $\log ($ hozam) abszolút értékét kellett figyelembe vennünk. Annak ellenére, hogy a modellünk hasonló piaci tényezőket tartalmazott, mint egy általános piaci stresszindex, azt láttuk, hogy a változókat egyesével bevonva a modellbe, jobban ki tudtuk használni az idősorokban rejlő információt, és így jelentősen javult a modell elörejelző képessége.

Mindezek alapján az elszámolóházak esetében a stressz meghatározásának lehetöségei a következőkben foglalhatók össze.

- A stresszesemény definiálásának legkézenfekvőbb és legegyszerübb módja az, ha az elszámolóház saját müködéséből indulunk ki, és a kockázatkezelési rendszerek outputjaira (például VaR-átlépések, letétikövetelmény-feltöltési felszólítások, nemfizetések, garancialehívások) alapozzuk a stresszjelzést.

- Ha azonban objektív piaci tényezőkön alapuló modellre van szükség, akkor jobb, ha az adott elszámolóház igényeinek megfelelően kialakított, testre szabott stresszmodellt alkalmazunk, mintsem egy külső, előregyártott indexet, egyrészt mert az általános stresszindexek nem veszik figyelembe a klíringiparág speciális tulajdonságait (magas fokú specializáció, szimmetrikus kitettségek, letéti számlák útvonalfüggősége stb.), másrészt mert az egyes idősorok külön-külön több információt tartalmaznak, mint egy kompozit index.

- A megfelelően kalibrált stresszmodell kialakításával párhuzamosan dönteni kell az első- és a másodfajú hiba relatív fontosságáról is. Ez a kérdés az intézmény kockázatkezelési stratégiájától függ. 


\section{Hivatkozások}

Bordo, M. D.-Dueker M. J.-Wheelock, D. C. [2002]: Aggregate Price Shocks and financial instability: a historical analysis. Economic Inquiry, Vol. 40. No. 4. 521-538. o. http:// dx.doi.org/10.1093/ei/40.4.521.

Carlson, M. A.-King, T.-Lewis, K. [2011]: Distress in the Financial Sector and Economic Activity. The B.E. Journal of Economic Analysis and Policy, Vol. 11. No. 1. http://dx.doi. org/10.2202/1935-1682.2697.

Cont, R.-Kокноцм, T. [2014]: Central Clearing of OTC Derivatives: biletaral vs. multilateral netting. Statistics and Risk Modeling, Vol. 31. No.1. 3-22. o. http://dx.doi.org/10.1515/ strm-2013-1161.

CsókA Péter-Herings, P. J.-J. [2016]: Decentralized clearing in financial networks. MTA KRTK KTI Mühelytanulmány, MT-DP 2016/3. http://dx.doi.org/10.2139/ssrn.2726569.

DodD-Frank Act [2010]: Dodd-Frank Wall Street Reform and Consumer Protection Act: https://www.congress.gov/111/plaws/publ203/PLAW-111publ203.pdf.

Duffie, D.-Scheicher, M.-Vuillemey, G. [2015]: Central clearing and collateral demand. Journal of Financial Economics, Vol. 116. No. 2. 237-256. o. http://dx.doi.org/10.1016/j. jfineco.2014.12.006.

EB [2013]: A Bizottság 153/2013/EU felhatalmazáson alapuló rendelete. 2012. december 19. HL, február 23. http://goo.gl/8d8LW6.

EuróPAi PARLAment És TANÁcs [2012]: A 648/2012/EU rendelete a tőzsdén kívüli származtatott ügyletekről, a központi szerződő felekről és a kereskedési adattárakról. Július 4. HL, július 27. http://goo.gl/bZ6NWV.

Hakкio, C. S.-Keeton, W. R. [2009]: Financial stress: What is it, how can it be measured, and why does it matter? Economic Review of Federal Reserve Bank of Kansas City, Vol. 94. No. 2. 5-50. o.

Heller, D.-VAuse, N. [2012]: Collateral requirements for mandatory central clearing of overthe-counter derivatives. BIS Working Paper, No. 373.

Hollo, D.-Kremer, M.-Lo Duca, M. [2012]: CISS - A composite indicator of systemic stress in the financial system. SSRN Electronic Journal. http://dx.doi.org/10.2139/ssrn.1611717. Hull, J. C. [2015]: Risk Management and Financial Institutions. John Wiley, Hoboken, NJ.

Illing, M.-LiU, Y. [2006]: Measuring financial stress in a developed country: An application to Canada. Journal of Financial Stability, Vol. 2. No. 3. 243-265. o. http://dx.doi. org/10.1016/j.jfs.2006.06.002.

Kiff, J.-Dodd, R.-Gullo, A.-Kazarian, E.-Lustgarten, I.-SAmpic, C.-Singh, M. [2010]: Making Over-the-Counter Derivatives Safer: The Role of Central Counterparties. Global Financial Stability Report, IMF.

Kiff, J.-Elliott, J.-Kazarian, E.-Scarlata, J.-Spackman, C. [2009]: Credit Derivatives: Systemic Risks and Policy Options. IMF Working Paper, Vol. 09. No. 254. http://dx.doi. org/10.5089/9781451874006.001.

KovÁcs ErzsÉBet [2009]: Pénzügyi adatok statisztikai elemzése. Tanszék Kft. Budapest.

Kumar, M. S.-Persaud, A. [2001]: Pure Contagion and Investors' Shifting Risk Appetite; Analytical Issues and Empirical Evidence. IMF Working Paper, No. 01/134.

Pirrong, C. [2009]: The economics of clearing in derivatives markets. Netting, asymmetric information, and the sharing of default risks through a central counterparty. SSRN Electronic Journal, http://dx.doi.org/10.2139/ssrn.1340660.

WALter György-Kenesei BALÁzs [2015]: Banki innovatív termékek a centralizált vállalati pénzgazdálkodáshoz. Pénzügyi Szemle, 60. évf. 3. sz. 319-332. o. 